\title{
Effect of municipal solid waste application on heavy metal distribution in different parts of wheat plant
}

\author{
Zafar Iqbal Khan ${ }^{1 *}$, Radiqa Arshad ${ }^{1}$, Kafeel Ahmad ${ }^{1}$, Naunain \\ Mehmood $^{2}$, Kinza Wajid ${ }^{1}$, Shehzadi Mahpara ${ }^{3}$, Muhammad Nadeem ${ }^{4}$, \\ Humayun Bashir ${ }^{1}$, Mudasra Munir ${ }^{1}$, Ifra Saleem Malik ${ }^{1}$, Asma Ashfaq ${ }^{1}$, \\ Maria Ghazzal $^{1}$, Mubeen Akhtar ${ }^{1}$ and Pervaiz Akhter ${ }^{1}$ \\ 1. Department of Botany, University of Sargodha, Sargodha-Pakistan \\ 2. Department of Zoology, University of Sargodha, Sargodha-Pakistan \\ 3. Department of Plant Breeding and Genetics, Ghazi University, D.G. Khan-Pakistan \\ 4. Institute of Food Science and Nutrition, University of Sargodha, Sargodha-Pakistan \\ *Corresponding author's email: zafar.khan@uos.edu.pk \\ Citation \\ Zafar Iqbal Khan, Radiqa Arshad, Kafeel Ahmad, Naunain Mehmood, Kinza Wajid, Shehzadi Mahpara, \\ Muhammad Nadeem, Humayun Bashir, Mudasra Munir, Ifra Saleem Malik, Asma Ashfaq, Maria Ghazzal, Mubeen \\ Akhtar and Pervaiz Akhter. Effect of municipal solid waste application on heavy metal distribution in different parts \\ of wheat plant. Pure and Applied Biology. Vol. 9, Issue 1, pp833-846. http://dx.doi.org/10.19045/bspab.2020.90089
}

\begin{tabular}{llll}
\hline \hline Received: 12/09/2019 & Revised: 01/12/2019 & Accepted: 13/12/2019 & Online First: 01/01/2020 \\
\hline
\end{tabular}

\section{Abstract}

The aim of current research was conducted during (November 2016-April 2017) to determine the contents of heavy metal in wheat (Triticum aestivum) variety (Faislabad-08) that was grown on soil irrigated with municipal solid waste and to estimate the health risk in human caused by the consumption of contaminated wheat crop. In the observed samples of soil, the concentrations (mg-kg ${ }^{-}$ ${ }^{1}$ ) of metals ranges from 22.76-35.46 for $\mathrm{Zn}, 2.18-3.18$ for Co, 2.51-3.18 for $\mathrm{Cd}$ and 78.89-84.63 for Fe. In recent findings the concentration of $\mathrm{Fe}$ was higher among all the treatments while lowest concentrations of metals were shown by $\mathrm{Cd}$ and $\mathrm{Co}$ both. The trends of heavy metals in root of wheat at T-1, T-2 and T-3 was: $\mathrm{Fe}>\mathrm{Zn}>\mathrm{Co}>\mathrm{Cd}$ and at $\mathrm{T}-4$ was: $\mathrm{Fe}>\mathrm{Zn}>\mathrm{Cd}>\mathrm{Co}$. The concentrations of heavy metals in shoot ranged from 17.56-28.98 for $\mathrm{Zn}, 1.54-2.8$ for Co, 1.88-2.92 for Cd and 17.74-27.42 for Fe respectively. The concentration of Fe showed higher concentration while the concentration of Co and $\mathrm{Cd}$ was lower in all treatments. The order of concentrations of heavy metals in grains at $\mathrm{T}-1$ was $\mathrm{Fe}>\mathrm{Cd}>\mathrm{Co}>\mathrm{Zn}$, at $\mathrm{T}-2$ was $\mathrm{Fe}>\mathrm{Zn}>\mathrm{Co}>\mathrm{Cd}$, at $\mathrm{T}-3$ and $\mathrm{T}-4$ was $\mathrm{Fe}>\mathrm{Co}>\mathrm{Zn}>\mathrm{Cd}$. $\mathrm{Zn}$ and $\mathrm{Cd}$ concentrations were lower and Fe concentration was higher among the all treatments. The health risk index values for each metal ranges from 0.01573 to 0.035067 for $\mathrm{Zn}, 0.139953$ to $0.262767 \mathrm{Co}, 6.624$ to 8.831 for $\mathrm{Cd}$ and 0.057577 to 0.169517 for Fe while the patterns of health risk index in all treatments was found in following order: $\mathrm{Cd}>\mathrm{Co}>\mathrm{Fe}>\mathrm{Zn}$.

Keywords: Heavy metals; Municipal solid waste; Transfer factor; Triticum aestivum

\section{Introduction}

Untreated or sewage is used to dampen $10 \%$ of the World's crops, instead of the global survey of waste water irrigation. In many countries this is a highly hidden practice and illegal or outlawed. Therefore, various farmers used the sewage because it acts as an effective fertilizer, even for the duration of 
scarcities, also it is free and ample [1-4]. The waste water use by farmers is not much more effective. By commanding bans on its use it cannot be ignored. The community policy fabricators and proposers want to provoke the certainty and faces the dare in an inventive method [5].

The sewage waste is greatly used as irrigation because water is full of various nutrients. For the slight activities, where forage, fibre or seed crops are developed and can be dampened with the average primary and secondary sewage wastes or overflows, the sewage waste can be used as extraordinary, well-managed "manure farms,". Therefore, many agronomic features that are associated to the soils and crops has been also engaged into interpretation [6].

The application of water to soil for the purpose of providing the water moisture that is essential or vital for plant growth it is referred as irrigation. In the enhancement of crop yields and stabilizing production irrigation plays a great role [7]. In partialdamp and tropical areas, irrigation is frequently essential on complementary origins, whereas irrigation is important for economically viable agriculture in the semiparched and dry areas [8].

These investigations shown the gainful part clinched alongside reuse from claiming wastewater to expanding crop yield without or with insignificant dangers of the plant, soil, Groundwater Also wellbeing [9-11]. Those range about area to a chance to be irrigated for wastewater expanded the worries in those Ecological meanings [12].

Sewage slime will be the strong by-result of provincial or mechanical wastewater medication plants which need been spread on the land for decades, and its use will prone increment later on. Those item Milorganite, a dried ooze need been utilized broadly Previously, North America since 1927 there need aid large portions reports starting with everywhere throughout those globe that sewage ooze material camwood makes viably utilized as a sourball of compost for crop yield and for moving forward physical Also concoction properties from claiming soils [13].

The expanded supply from claiming significant plant supplements especially $\mathrm{N}$ and $\mathrm{P}$, alongside exactly of the key micronutrient (e.g. $\mathrm{Zn}, \mathrm{Cu}$, Mo and $\mathrm{Mn}$ ) also change in the soil physical properties for those requisition about sewage slime [14-17]. The aim of current research was to determine the contents of heavy metal in different varieties of wheat (Triticum aestivum) that was grown on irrigated soil and to estimate the health risk in human caused by the consumption of contaminated wheat crop. To analyse the heavy metal contents in wheat parts and in soil. To check the effect of heavy metals on humans. To estimate the different indices like correlation, pollution load index, bioconcentration factor, transfer factor, enrichment factor, daily intake of metals and health risk index.

\section{Materials and methods Study area}

In order to analyze heavy metal content in the wheat (Triticum aestivum L.) using municipal solid waste, a pot experiment was conducted. At University of Sargodha Department of botany, the present research work was conducted for the duration of 20162017. The temperature of Sargodha is very red-hot and realistic, and in winters it is cold. Maximum temperature increases up to $50^{\circ} \mathrm{C}$ in summer and in winter minimum up to $12^{\circ} \mathrm{C}$. For citrus production Sargodha is very famous.

\section{Cultivation of plant}

For the duration of 2016 vigorous seeds of wheat were accumulated. In current study, one variety of wheat, Faislabad-08 was used. The conducted experiment consists of four treatments, with three replicates of the selected crop. Took 12 pots and filled with soil. After that, seeds were cultivated in four 
cultivation groups, consisting of one control group (ground soil) and the remaining three with different percentages of municipal solid waste (municipal solid waste treatment). Twelve seeds in the form of pairs were sowed in each pot. The experiment consist of four treatments: T-1 was consisted of $100 \%$ ground soil, T-2 was consisted of $25 \%$ municipal solid waste and $75 \%$ ground soil, T-3 was consisted of $50 \%$ municipal solid waste and $50 \%$ ground soil, T-4 was consisted of $75 \%$ municipal solid waste and $25 \%$ ground soil.

For 6 months pot treatments were accompanied in a usual atmosphere system (November, 2016 to April, 2017). Municipal solid waste was found from municipal solid waste pools or areas that were present near Sargodha University (university of Sargodha). Seeds of altered selections of wheat were developed in mud pots $(15 \mathrm{~cm}$ in height and $20 \mathrm{~cm}$ in diameter) for research purpose, at the end of November, 2016. In each pot $3 \mathrm{~kg}$ of soil was added. The trial pots were watered with ground water. For each treatment $(25 \%, 50 \%$, and $75 \%$ municipal solid waste) 3 pots were used. In a week pots were watered with two times. In the form of pairs twelve seeds were seeded in separately pot. The information about germination of seed was documented. For proper growth, five plants remained in each pot after germination. Maturation period was 5 months. Different morphological parameters of different varieties of wheat were also observed. At ripeness plant height was measured. The quantity of leaf for each plant was also calculated, associating with plants which were grown-up in perfect conditions. Harvesting was done during the month of April, 2017.

\section{Sample collection and preparation}

After harvesting, the whole plant samples were collected from each pot. The samples after drying in the air were then oven-dried at $72^{\circ} \mathrm{C}$ for few days. After removing from the oven, grains were separated from the spikes and ground in an electrical grinder into fine powder, for heavy metal detection. $1 \mathrm{~g}$ of each sample was taken. For the digestion of samples, wet digestion method was used.

\section{Method of wet digestion}

The dried samples were placed in a small conical flask and digested with conc. $\mathrm{HNO}_{3}$ and $\mathrm{H}_{2} \mathrm{O}_{2}$ 1:2 on a hot plate. When fumes disappear, samples were removed from the heat and $\mathrm{H}_{2} \mathrm{O}_{2}$ was further added to attain transparent solution and again placed on the hot plate. Digestion continued until a colorless solution appear and allow to cool. After cooling, dilute all the samples in a measuring flask up to $50 \mathrm{ml}$ as final volume. The samples were then filtered through Whatmann filter paper No. 42.

\section{Soil digestion}

The soil samples were collected from the upper 3-5 cm layer of the soil from each pot. After drying in the air, soil samples were placed in the oven for two days at $65^{\circ} \mathrm{C}$. The samples were digested in the same manner.

\section{Metals analysis}

All the digested samples were then subjected to Atomic Absorption Spectrophotometer (Perkin-Elmer Corp., 1980) to detect heavy metals in them. The metals to be analyzed were: cobalt $(\mathrm{Co})$, zinc $(\mathrm{Zn})$, iron $(\mathrm{Fe})$, and cadmium $(\mathrm{Cd})$. For detection, the standard solution of different metals was also prepared from the stock solution, to obtain a calibration curve.

\section{Quality control}

To assess the reliability and assurance of the data, such measures were taken. By comparing with the international standards, the precision of the results can be done. The repeated analyses of the examined samples can also verify the accuracy of the analyses.

\section{Statistical analysis Variance}

Statistical Program for Social Sciences (SPSS 16) was used for statistical analysis. ANOVA (One-way analysis of variance) was 
useful in maintenance of soil, root, shoot and grains of wheat.

\section{Correlation}

Using the software package SPSS (version 16.0), the correlation results obtained. To assess soil-plant interaction, "Pearson's correlation coefficient" was calculated. It is a bivariant process. The significant correlation was at $0.001,0.01$ and 0.5 probability stages [18].

\section{Pollution load index}

The pollution load index (PLI) for each cure was controlled out [19].

$\mathrm{PLI}=$ Concentration of metals in investigated soil/Reference values of metals in soil

\section{Bioconcentration factor}

To calculate the transport of metals from soil to the plant parts, a bioconcentration factor (BCF) was calculated [20].

$\mathrm{BCF}=$ Concentration of metals in root/ Concentration of metals in soil

\section{Transfer factor}

To estimate the transfer of heavy metals (mg$\mathrm{kg}^{-1}$ ) from grains to the root or to the other parts of the plants, transfer factor (TF) was calculated [20].

$\mathrm{BCF}=$ Concentration of metals in grain/ Concentration of metals in root

\section{Enrichment factor}

In order to calculate the extent of soil pollution, an index enrichment factor (EF) was calculated following Al-Hwaiti and AlKhashman [22].

$\mathrm{EF}=$ Concentration of examined metal in amended soil/Concentration of metal in control soil

\section{Daily intake of metal}

By different ways toxic heavy metal enters into the human body sometimes it may be by oral intake, by inhalation or by dermal contact [23]. Daily intake of metal (DIM) was computed according to Sajjad et al. [24]. $\mathrm{DIM}=\mathrm{C}_{\text {metal }} \times \mathrm{D}_{\text {food intake }} / \mathrm{B}_{\text {average weight }}$ Where: $\mathrm{C}_{\text {metal }}$ described as the heavy metal concentrations in food crop $\left(\mathrm{mg}-\mathrm{kg}^{-1}\right), \mathrm{D}_{\text {food }}$ intake is the daily intake of food crop ( $\mathrm{kg} /$ day)

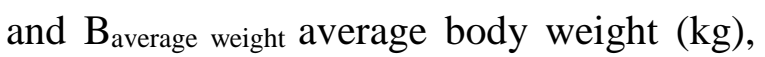
respectively.

The average body weight was taken as 55.9 $\mathrm{kg}$ [25] and daily intake of metal in wheat as $0.242 \mathrm{~kg} /$ person/day respectively [26].

\section{Health risk index}

Health risk index (HRI) was defined as "the relation of expected contact to metal through food crop" and verbal reference prescription according to Cui et al. [20].

$\mathrm{HRI}=\mathrm{DIM} / \mathrm{R}_{\mathrm{f}} \mathrm{D}$

Oral reference dose $\left(R_{f} D\right)$ is the maximum acceptable oral dose of heavy metals. An index $>1$ is measured risky for human [27].

\section{Results and discussion}

\section{Morphological parameters}

The effect of municipal solid waste on morphological attributes such as root length, shoot length, leaf length, leaf width and leaf area of wheat variety (Faislabad-08). The concluded non-significant effect $(p>0.05)$ of treatments on leaf length, leaf area, root length, shoot length and leaf width. In our recent findings, T-2 showed the highest values of different parameters while T-1 showed the lowest values of all parameters (Table 1). The results showed the effect of municipal solid waste on different parts of plants due to this heavy metal content of soil which exerts toxic effects on plants. Day et al. [28] reported the similar results as compared to the recent findings. All the morphological parameters of plants were considerably reduced by increasing dose of municipal solid waste. In our recent investigation the values of root length were quite similar as suggested by Farid [29].

Soil

Analysis of variance described the insignificant outcome $(p>0.05)$ of altered trials on the meditations of metals like; zinc $(\mathrm{Zn})$, cobalt $(\mathrm{Co})$, cadmium $(\mathrm{Cd})$ and iron $(\mathrm{Fe})$ in soil used to grown the wheat variety (Faislabad-08) (Table $2 \& 3$ ).

In the observed samples of soil, the concentrations $\left(\mathrm{mg}-\mathrm{kg}^{-1}\right)$ of metals ranges 
from 22.76-35.46 for $\mathrm{Zn}, 2.18-3.18$ for $\mathrm{Co}$, 2.51-3.18 for $\mathrm{Cd}$ and 78.89-84.63 for $\mathrm{Fe}$ while the trends of metals in soil samples at T-1 and T-2 was: $\mathrm{Fe}>\mathrm{Zn}>\mathrm{Cd}>\mathrm{Co}$, and at T-3 and T-4 was: $\mathrm{Fe}>\mathrm{Zn}>\mathrm{Co}>\mathrm{Cd}$ respectively. In recent findings the concentration of $\mathrm{Fe}$ was higher among all the treatments while lowest concentrations of metals were shown by $\mathrm{Cd}$ and Co both. The concentrations of all heavy metals was fall within the permissible limit of Fe (5000 mg-kg-1 $)$, Zn (300 mg-kg-1), Co (100 mg-kg-1) and $\mathrm{Cd}\left(3 \mathrm{mg}-\mathrm{kg}^{-1}\right)$ as discussed by the FAO/WHO [30]. This condition was owed to the higher values of $\mathrm{pH}$ of soil. In soil the dense metal distribution was effected by the various properties of soil such as electrical conductivity and $\mathrm{pH}$ etc. as reported by Miras et al. [31] and Zhou et al. [32]. The large amount of heavy metals added to the soil, therefore the production of wheat was reduced either by the toxicity of metals or due to deficiency of Fe [33]. The values of
$\mathrm{Cd}$ in soil were lower as discussed by the Kashem and Singh [34] as compared to current results. Cadmium was found in all rocks (mineral fertilizers) and in soil also, it was a toxic metal.

Cadmium has many useful aspects (includes metal coatings, plastics pigments etc.) as well as harmful aspects includes severe damage of lungs that was due to the breathing of $\mathrm{Cd}$ in high amount [35]. In municipal solid waste, Cd was found in higher amounts therefore it shows effect on plants, it was found as a $\mathrm{Zn}$ ore, smelters, agricultural applications of fertilizer, municipal solid waste [36].

According to recent study, Fe concentration was lower as reported by the Moradia et al. [37]. They studied the contaminated soil having high quantity of heavy metals, this might be due to the industrial activities therefore their results showed high concentration of metals like for Fe.

Table 1. Mean values of morphological parameters of wheat

\begin{tabular}{|c|c|c|c|c|c|}
\hline Parameters & T-1 & T-2 & T-3 & T-4 & Mean square \\
\hline Root length & $11.66 \pm 1.3$ & $8.6 \pm 0.98$ & $11.93 \pm 1.02$ & $13.16 \pm 1.77$ & $11.303^{\text {ns }}$ \\
\hline Shoot length & $49.23 \pm 2.59$ & $58.93 \pm 2.67$ & $53.5 \pm 2.6$ & $56.6 \pm 2.65$ & $52.784^{\text {ns }}$ \\
\hline Leaf length & $21.2 \pm 1.2$ & $25.46 \pm 1.01$ & $23.53 \pm 1.04$ & $22.86 \pm 1.05$ & $9.342^{\text {ns }}$ \\
\hline Leaf width & $0.66 \pm 0.99$ & $0.83 \pm 1.01$ & $0.63 \pm 0.97$ & $1.1 \pm 0.98$ & $0.136^{\text {ns }}$ \\
\hline Leaf area & $10.64 \pm 1.04$ & $16.57 \pm 0.99$ & $10.45 \pm 0.98$ & $18.92 \pm 1.02$ & $54.637^{\text {ns }}$ \\
\hline
\end{tabular}

Ns = non-significant

\section{Root}

ANOVA depicted the insignificant outcome $(p>0.05)$ of trials on the absorptions of metals i.e.: $\mathrm{Zn}, \mathrm{Cd}, \mathrm{Fe}$, and $\mathrm{Co}$ in root of wheat variety (Faislabad-08) (Table 2). The trends of heavy metals in root of wheat at T-1, T-2 and $\mathrm{T}-3$ was: $\mathrm{Fe}>\mathrm{Zn}>\mathrm{Co}>\mathrm{Cd}$ and at $\mathrm{T}-4$ was: $\mathrm{Fe}>\mathrm{Zn}>\mathrm{Cd}>\mathrm{Co}$ and the concentrations of heavy metals ranged for $\mathrm{Zn}$ (22.19-34.49), Co (2.04-2.94), Co (2.04-2.94), Cd (2.013.05) and $\mathrm{Fe}$ (23.39-35.39) (Table 3). In current study, Fe showed the highest concentrations while $\mathrm{Co}$ and $\mathrm{Cd}$ showed lower concentrations among all the treatments.
The cadmium concentration has no wellknown effects in plants and are exclusively harmful [38]. Due to the deficiency of $\mathrm{Zn}$ metal it causes various problems like insufficient consumption of nutrition, reduced the absorption and causes disorders in the metabolism of $\mathrm{Zn}$ [39].

The uptake of heavy metals from the soil to roots was done due to the transport of water in plants through the process of active transport [40]. The concentration of $\mathrm{Zn}$ was higher than the readings of Al-Othman et al. [41].

In plants, $\mathrm{Cd}$ was carried out from the roots to the edible parts of the plants such as leaves 
fruits and seeds. It was also found in the milk of animals and in fatty tissues [42]. The harmful effect of $\mathrm{Cd}$ on the wheat influences the growth of root [43].

Table 2. Analysis of variance for heavy metals in soil, root, shoot and grains of wheat

\begin{tabular}{|c|c|c|c|c|}
\hline \multicolumn{5}{|c|}{ Mean square } \\
\hline Metals & Cd & Fe & Zn & Co \\
\hline Soil & $1.017^{\mathrm{ns}}$ & $18.359^{\mathrm{ns}}$ & $144.185^{\mathrm{ns}}$ & $0.538^{\mathrm{ns}}$ \\
\hline Root & $0.687^{\mathrm{ns}}$ & $82.691^{\mathrm{ns}}$ & $82.757^{\mathrm{ns}}$ & $0.378^{\text {ns }}$ \\
\hline Shoot & $0.967^{\mathrm{ns}}$ & $92.841^{\mathrm{ns}}$ & $51.865^{\mathrm{ns}}$ & $1.076^{\mathrm{ns}}$ \\
\hline Grain & $0.528^{\mathrm{ns}}$ & $217.522^{\mathrm{ns}}$ & $1.190^{\mathrm{ns}}$ & $1.389^{\mathrm{ns}}$ \\
\hline
\end{tabular}

Table 3. Mean concentration (mg/kg) of cadmium, iron, zinc and cobalt in soil root shoot grain of wheat

\begin{tabular}{|c|c|c|c|c|}
\hline Treatment & T-1 & T-2 & T-3 & T-4 \\
\hline \multicolumn{5}{|c|}{ Cadmium } \\
\hline Soil & $2.58 \pm 2.12$ & $2.91 \pm 2.13$ & $2.51 \pm 2.11$ & $3.18 \pm 2.14$ \\
\hline Root & $2.01 \pm 1.12$ & $2.49 \pm 1.13$ & $1.93 \pm 1.12$ & $3.05 \pm 1.14$ \\
\hline Shoot & $2.01 \pm 1.13$ & $1.88 \pm 1.12$ & $1.92 \pm 1.13$ & $2.92 \pm 1.14$ \\
\hline Grain & $1.73 \pm 0.12$ & $1.87 \pm 0.13$ & $1.53 \pm 0.12$ & $2.04 \pm 0.13$ \\
\hline \multicolumn{5}{|c|}{ Iron } \\
\hline Soil & $78.89 \pm 4.04$ & $81.56 \pm 3.56$ & $84.63 \pm 3.29$ & $80.12 \pm 3.49$ \\
\hline Root & $23.39 \pm 1.34$ & $33.29 \pm 1.26$ & $31.51 \pm 1.29$ & $35.39 \pm 1.33$ \\
\hline Shoot & $17.74 \pm 1.44$ & $25.21 \pm 1.36$ & $27.41 \pm 1.29$ & $27.42 \pm 1.29$ \\
\hline Grain & $9.31 \pm 2.99$ & $24.26 \pm 2.36$ & $26.08 \pm 2.89$ & $27.41 \pm 2.99$ \\
\hline \multicolumn{5}{|c|}{ Zinc } \\
\hline Soil & $22.76 \pm 2.4$ & $26.99 \pm 2.19$ & $27.51 \pm 2.14$ & $35.46 \pm 2.29$ \\
\hline Root & $22.19 \pm 1.21$ & $29.28 \pm 1.19$ & $27.05 \pm 1.04$ & $34.49 \pm 1.29$ \\
\hline Shoot & $17.56 \pm 1.11$ & $22.55 \pm 1.31$ & $19.08 \pm 1.04$ & $28.98 \pm 1.19$ \\
\hline Grain & $1.09 \pm 1.05$ & $2.33 \pm 1.09$ & $2.26 \pm 1.08$ & $2.43 \pm 1.19$ \\
\hline \multicolumn{5}{|c|}{ Cobalt } \\
\hline Soil & $2.18 \pm 2.15$ & $2.85 \pm 2.11$ & $2.88 \pm 2.12$ & $3.18 \pm 2.11$ \\
\hline Root & $2.04 \pm 1.27$ & $2.77 \pm 1.1$ & $2.86 \pm 1.12$ & $2.94 \pm 1.13$ \\
\hline Shoot & $1.54 \pm 1.11$ & $2.73 \pm 1.12$ & $2.43 \pm 1.13$ & $2.8 \pm 1.13$ \\
\hline Grain & $1.39 \pm 0.12$ & $1.91 \pm 0.13$ & $2.29 \pm 0.14$ & $2.61 \pm 0.13$ \\
\hline
\end{tabular}

\section{Shoot}

ANOVA revealed the insignificant effect $(\mathrm{P}>0.05)$ of all trials on the concentration of heavy metals like $\mathrm{Zn}, \mathrm{Co}, \mathrm{Fe}$ and $\mathrm{Cd}$ in shoot of wheat variety (Faislabad-08) (Table 2). The sequence of concentrations of heavy metals in shoot of wheat at $\mathrm{T}-1$ was: $\mathrm{Fe}>\mathrm{Zn}>\mathrm{Cd}>\mathrm{Co}$, at T-2 and T-3 was: $\mathrm{Fe}>\mathrm{Zn}>\mathrm{Co}>\mathrm{Cd}$ and at T-4 was: $\mathrm{Zn}>\mathrm{Fe}>\mathrm{Cd}>\mathrm{Co}$. The concentrations of heavy metals ranged from 17.56-28.98 for $\mathrm{Zn}, 1.54$ 2.8 for Co, 1.88-2.92 for Cd and 17.74-27.42 for $\mathrm{Fe}$ respectively (Table 3). The concentration of $\mathrm{Fe}$ showed higher concentration while the concentration of $\mathrm{Co}$ and $\mathrm{Cd}$ was lower in all treatments.

In wheat plants, the growth of root and shoot was reduced due to the toxicity of Cd [44]. The accumulation of heavy metals in plants enhances the antioxidant processes of enzymes [45]. The shoot growth of plants was greatly affected by the intake of $\mathrm{Cd}$ because it was poisonous and also induces peroxidation of lipid and causes stress [43]. Singh et al. (2010) discussed the higher 
concentration of $\mathrm{Cd}$ as compared to current investigation.

\section{Grains}

Analysis of variance demonstrated the nonsignificant effect $(p>0.05)$ of all treatments on the concentrations of heavy metals $(\mathrm{Zn}$, $\mathrm{Cd}, \mathrm{Co}$ and $\mathrm{Fe}$ ) in grains of wheat variety (Faislabad-08) (Table 2). In wheat grains, the concentrations of heavy metals ranges from1.09 to 2.43 for $\mathrm{Zn}, 1.39$ to 2.61 for Co, 1.53 to 2.04 for $\mathrm{Cd}$ and 9.31 to 27.41 for $\mathrm{Fe}$ correspondingly. The direction of absorptions of dense metals at trial- 1 was $\mathrm{Fe}>\mathrm{Cd}>\mathrm{Co}>\mathrm{Zn}$, at $\mathrm{T}-2$ was $\mathrm{Fe}>\mathrm{Zn}>\mathrm{Co}>\mathrm{Cd}$, at T-3 and T-4 was $\mathrm{Fe}>\mathrm{Co}>\mathrm{Zn}>\mathrm{Cd}$. $\mathrm{Zn}$ and $\mathrm{Cd}$ concentrations were lower and $\mathrm{Fe}$ concentration was higher among the all treatments (Table 3).

The change in concentrations occurred due to the higher dose of municipal solid waste. FAO/WHO [30] recommended the permissible limits for all heavy metals except $\mathrm{Cd}$ because its mean concentration in grains was above than the $0.2 \mathrm{mg}-\mathrm{kg}^{-1}$.

Cd was highly toxic metal and it was not known in animals especially for any important biological function and it causes malfunctioning of metabolic processes [46]. The great of effect of $\mathrm{Cd}$ in humans was the dysfunction of the kidneys [47]. The metal $\mathrm{Zn}$ has great importance in wound healing, protein and DNA synthesis and also in immune function [48]. In soils, $\mathrm{Zn}$ can interrupt the activities of microorganisms and influences negative effect on the breakdown of organic matter [49].

In all living organisms, $\mathrm{Fe}$ was an essential element as it takes a part in transport and in biological oxidations. Iron was less discussed element in the analysis of wheat grains. The average $\mathrm{Fe}$ contents was lower than the findings of Hassan et al. [50] and higher than the permissible limit of $20 \mathrm{mg}-\mathrm{kg}^{-1}$. Jamali et al. [51] reported the lower concentration of Fe as compared to current results.

\section{Correlation}

In soil and root the correlation was positive and non-significant for $\mathrm{Fe}$ while positive and significant for $\mathrm{Zn}, \mathrm{Co}$ and $\mathrm{Cd}$. In the root and shoot the correlation was positive and significant for $\mathrm{Zn}$ and Co while positive and non-significant for $\mathrm{Cd}$ and $\mathrm{Fe}$. In shoot and grains the correlation was positive and nonsignificant for $\mathrm{Zn}$, Co and $\mathrm{Cd}$ while positive and significant for Fe (Table 4). The food chain was a great exposure of transport of metals from soil to plants. In the soils, high accumulation of heavy metals was found and in the industrial regions edible parts of the crops were cultivated [37]. Significant and positive correlation suggested the strong impact of organic matter on the heavy metals [52]. If heavy metals showed significant correlation it means that they obtained from the same source. Positive and significant correlation of $\mathrm{Zn}$ was also recommended by the Meng et al. [52].

Table 4. Correlation between soil to root, root to shoot and shoot to grains of wheat

\begin{tabular}{|c|c|c|c|}
\hline \multicolumn{5}{|c|}{ Correlation } \\
\hline Heavy Metals & Soil-Root & Root-Shoot & Shoot-Grains \\
\hline Zn & $0.959^{*}$ & $0.959^{*}$ & $0.675^{\mathrm{ns}}$ \\
\hline Co & $0.975^{*}$ & $0.954^{*}$ & $0.825^{\mathrm{ns}}$ \\
\hline Cd & $0.995^{* *}$ & $0.839^{\mathrm{ns}}$ & $0.745^{\mathrm{ns}}$ \\
\hline Fe & $0.397^{\mathrm{ns}}$ & $0.932^{\mathrm{ns}}$ & $0.994^{* *}$ \\
\hline
\end{tabular}

$*, * *=$ significant at 0.05 and 0.01 levels, $\mathrm{ns}=$ non-significant

\section{Pollution load index}

The sequence of effluence or PLI at T-1, T-2, T-3 and T-4 was: $\mathrm{Cd}>\mathrm{Fe}>\mathrm{Zn}>\mathrm{Co}$ while the standards of PLI for all heavy metals in all treatments ranged from $0.515049-0.802444$ for $\mathrm{Zn}, 0.23956-0.349451$ for Co, 1.684564- 
2.134228 for $\mathrm{Cd}$ and 1.386467-1.487346 for $\mathrm{Fe}$ (Table 5). In recent study, $\mathrm{Fe}$ and $\mathrm{Cd}$ showed PLI greater that means it has highly contaminated and have high environmental risk [53]. Cadmium showed higher PLI as compared to the findings of Bao et al. [54]. PLI was high because of various industrial and human activities as studied by the Uwah et al. [55].

Table 5. Pollution load index and enrichment factor of wheat

\begin{tabular}{|c|c|c|c|c|}
\hline Treatment & Zn & Co & Cd & Fe \\
\hline \multicolumn{5}{|c|}{ Pollution load index } \\
\hline T-1 & 0.515049 & 0.23956 & 1.731544 & 1.386467 \\
\hline T-2 & 0.610772 & 0.313187 & 1.95302 & 1.433392 \\
\hline T-3 & 0.622539 & 0.316484 & 1.684564 & 1.487346 \\
\hline T-4 & 0.802444 & 0.349451 & 2.134228 & 1.408084 \\
\hline \multicolumn{5}{|c|}{ Enrichment factor } \\
\hline T-1 & 0.021291 & 0.116046 & 4.995552 & 0.015781 \\
\hline T-2 & 0.038379 & 0.121972 & 4.787466 & 0.039777 \\
\hline T-3 & 0.036522 & 0.144715 & 4.541243 & 0.041209 \\
\hline T-4 & 0.030465 & 0.149377 & 4.779249 & 0.045749 \\
\hline
\end{tabular}

\section{Bioconcentration factor}

The order of BCF values at T-1 and T-2 was: $\mathrm{Zn}>\mathrm{Co}>\mathrm{Cd}>\mathrm{Fe}$, at $\mathrm{T}-3$ was: $\mathrm{Co}>\mathrm{Zn}>\mathrm{Cd}>\mathrm{Fe}$ and at T-4 was: $\mathrm{Zn}>\mathrm{Cd}>\mathrm{Co}>\mathrm{Fe}$. The values of BFC in all samples ranged from 0.972645 to 1.084846 for $\mathrm{Zn}, 0.924528$ to 0.903056 for Co, 0.768924 to 0.959119 for $\mathrm{Cd}$ and 0.296489 to 0.441712 for $\mathrm{Fe}$ respectively (Table 6).

The bioconcentration factor was the link between the available contents in the soil and absorbed by the plants. It was determined by the calculation of the ratio of metal concentration in the plants to soil (Lago-Vila et al., 2015). The plants accumulate most of the heavy metals in the roots and it does not transfer them to the shoot, here it behaving as a phytostabalizer related to Simon (2005). The bioconcentration factor values of $\mathrm{Cd}$ was greater than 1 due to the irrigation of wheat, rice etc. with drained water. The greater the BCF values than 1 showed the high accumulation and BCF values lower than 1 exhibiting the low accumulation in plants (Mahmoud and Ghoneim, 2016).

\section{Transfer factor}

The trends of TF in all heavy metals at T-1 was: $\mathrm{Cd}>\mathrm{Co}>\mathrm{Fe}>\mathrm{Zn}, \quad$ at $\mathrm{T}-2$ was:
$\mathrm{Cd}>\mathrm{Fe}>\mathrm{Co}>\mathrm{Zn}$, at $\mathrm{T}-3$ was: $\mathrm{Fe}>\mathrm{Co}>\mathrm{Cd}>\mathrm{Zn}$ and at $\mathrm{T}-4$ was: $\mathrm{Co}>\mathrm{Fe}>\mathrm{Cd}>\mathrm{Zn}$ where transfer factor values ranged from 0.049121 to 0.083549 for $\mathrm{Zn}, 0.681373$ to 0.887755 Co, 0.668852 to 0.860697 for $\mathrm{Cd}, 0.398033$ to 0.827674 for Fe respectively (Table 6).

Transfer factor means the transfer of heavy metals to the whole plants especially to the edible parts of plants. According to current findings, the TF values of Co was above than the readings suggested by the Lago-Vila et al. [56]. In wheat crop (roots, shoots and grains), showed the specific way for the translocation of heavy metals [57]. In wheat plants, the absorption of toxic metals inhibited the relation between the root, shoot and grain [58]. The heavy metal concentration between the root and shoot has large differences that shows the limits for the internal transport of heavy metals from root to the shoot and grains [59].

\section{Enrichment factor}

The order of EF for each metal at T-1 was: $\mathrm{Cd}>\mathrm{Co}>\mathrm{Zn}>\mathrm{Fe}$, at $\mathrm{T}-2, \mathrm{~T}-3$ and $\mathrm{T}-4$ was: $\mathrm{Cd}>\mathrm{Co}>\mathrm{Fe}>\mathrm{Zn}$ while the range of $\mathrm{EF}$ for each metal was 0.021291-0.38379 for $\mathrm{Zn}$, 0.116046-0.149377 for Co, 4.541243- 
4.995552 for $\mathrm{Cd}$ and $0.015781-0.045749$ for Fe respectively (Table 5).

Enrichment factor was determined to examine the effect of metal concentration on soil by naturally and anthropogenically [60]. The higher EF values (greater than 1) indicated that plants have many anthropogenic sources for heavy metals that might be carried out from the fertilizers, urbanizations, waste water irrigation and these were then used for different industrial activities [61]. Alghobar and Suresha [62] also studied the EF standards of different metals.

Table 6. Bioconcentration factor and transfer factor for wheat

\begin{tabular}{|c|c|c|c|c|}
\hline Treatment & Zn & Co & Cd & Fe \\
\hline \multicolumn{5}{|c|}{ Bioconcentration factor } \\
\hline T-1 & 0.974956 & 0.93578 & 0.77907 & 0.296489 \\
\hline T-2 & 1.084846 & 0.97193 & 0.85567 & 0.408166 \\
\hline T-3 & 0.983279 & 0.993056 & 0.768924 & 0.372327 \\
\hline \multicolumn{5}{|c|}{ Transfer factor } \\
\hline T-1 & 0.972645 & 0.924528 & 0.959119 & 0.441712 \\
\hline T-2 & 0.049121 & 0.681373 & 0.860697 & 0.398033 \\
\hline T-3 & 0.079577 & 0.689531 & 0.751004 & 0.728747 \\
\hline T-4 & 0.083549 & 0.800699 & 0.792746 & 0.827674 \\
\hline
\end{tabular}

\section{Daily intake of metals}

The order for DIM at T-1 was: $\mathrm{Fe}>\mathrm{Co}>\mathrm{Zn}>\mathrm{Cd}$, at $\mathrm{T}-2$ was: $\mathrm{Fe}>\mathrm{Cd}>\mathrm{Zn}>\mathrm{Co}$, at T-3 and T-4 was: $\mathrm{Fe}>\mathrm{Cd}>\mathrm{Co}>\mathrm{Zn}$ while the values for daily intake of metals ranged from 0.006797-0.008528 for $\mathrm{Zn}, \quad 0.007879$ 0.009914 for $\mathrm{Co}, 0.00658-0.012165$ for $\mathrm{Cd}$ and $0.008918-0.014806$ for Fe respectively (Table 7).

To estimate the exposure of heavy metals in humans, there were various paths but most essential one was food chain. The consumption of heavy metals to the entire plant or crops can be calculated by studying food chain [63]. Daily intake of metal values of metals like $\mathrm{Fe}, \mathrm{Cd}$ and $\mathrm{Zn}$ were also determined by the Balkhair and Ashraf [63]. Osaili [64] reported the DIM values of Co lower than the recent investigation. Khan et al. [65] concluded that there was no effect of consumption of wheat crop due to the use waste water irrigated soil for the growth of crops.

\section{Health risk index}

The health risk index values for each metal ranges from 0.01573 to 0.035067 for $\mathrm{Zn}$, 0.139953 to $0.262767 \mathrm{Co}, 6.624$ to 8.831 for $\mathrm{Cd}$ and 0.057577 to 0.169517 for Fe while the patterns of HRI were similar among all treatments $(1,2,3$ and 4$)$ of metals as: $\mathrm{Cd}>\mathrm{Co}>\mathrm{Fe}>\mathrm{Zn}$ respectively (Table 7).

The health risk index was calculated to evaluate the comparison between the risk for health that was related to wheat grown in soils such as amended and non-amended contaminated with heavy metal. Similar results were recommended by the Singh et al. [66] of wheat that was grown by a waste water irrigated soil. Balkhair and Ashraf [63] suggested that the detection of health hazard for each pollutant was done by estimating the routes of exposure to target organisms. The basic routes through which heavy metals enters into the human body was the food chain [67]. 
Table 7. Daily intake of metal and health risk index via intake of Triticum aestivum

\begin{tabular}{|c|c|c|c|c|}
\hline Treatment & Zn & Co & Cd & Fe \\
\hline \multicolumn{5}{|c|}{ Daily intake of metals } \\
\hline T-1 & 0.006797 & 0.007879 & 0.00658 & 0.008918 \\
\hline T-2 & 0.008528 & 0.008312 & 0.008702 & 0.011256 \\
\hline T-3 & 0.007403 & 0.009914 & 0.010433 & 0.011732 \\
\hline T-4 & 0.007533 & 0.008442 & 0.012165 & 0.014806 \\
\hline \multicolumn{5}{|c|}{ Health risk index } \\
\hline T-1 & 0.01573 & 0.139953 & 7.489 & 0.057577 \\
\hline T-2 & 0.033623 & 0.192302 & 8.096 & 0.150036 \\
\hline T-3 & 0.032613 & 0.230558 & 6.624 & 0.161291 \\
\hline T-4 & 0.035067 & 0.262767 & 8.831 & 0.169517 \\
\hline
\end{tabular}

\section{Conclusion}

Municipal solid waste is used as a soil amender to enhance the nutrient content of soil and crop productivity. Application of municipal solid waste enhances the morphological parameters of wheat by providing significant amount of nutrient but it also contains toxic metals. The values of all metals in all parts of wheat plant were found within the permissible limit except for the $\mathrm{Cd}$. The values of PLI for all metals were less than 1 except for Fe and Cd. The BCF and TF for all metals was less than 1 . The values of health risk index for the $\mathrm{Cd}$ were greater than 1 indicated that the consumption of municipal solid waste treated wheat is not safe for human.

\section{Authors' contributions}

Conceived and designed the experiments: ZI Khan, K Ahmad \& IR Noorka, Performed the experiments: R Arshad, P Akhter \& H Bashir, Analyzed the data: K Wajid, Contributed reagents/ materials/ analysis tools: $\mathrm{M}$ Nadeem, M Ghazzal, N Mehmood \& M Akhtar, Wrote the paper: IS Malik, S Mahpara, A Ashfaq \& M Munir.

\section{References}

1. Khan ZI, Iqbal S, Ahmad K, Ashfaq A, Bashir H, Dogan Y (2019a). Assessment of heavy metal content of wheat irrigated with wastewater in Sargodha, Pakistan: Implications for human health. Trace Elem Electroly 36(2): 82-92.
2. Khan ZI, Safdar H, Ahmad K, Wajid K, Bashir H, Ugulu I \& Dogan Y (2019b). Health risk assessment through determining bioaccumulation of iron in forages grown in soil irrigated with city effluent. Environ Sci Pollut Res 26(14): 14277-14286.

3. Khan ZI, Ahmad K, Rehman S, Ashfaq A, Mehmood N, Ugulu I \& Dogan Y (2019c). Effect of sewage water on accumulation of metals in soil and wheat in Punjab, Pakistan. Pak J Anal Environ Chem 20(1): 60-66.

4. Khan ZI, Nisar A, Ugulu I, Ahmad K, Wajid K, Bashir H \& Dogan Y (2019d). Determination of cadmium concentrations of vegetables grown in soil irrigated with wastewater: Evaluation of health risk to the public. Egypt $J$ Bot IN PRESS https://doi.org/10.21608/EJBO.2019.99 69.1296

5. Scott C, Faruqui NI \& Raschid L (2004). Wastewater Use in Irrigated Agriculture. Confronting the Livelihood and Environmental Realities.

6. Bouwer H \& Idelovitch E (1987). Quality requirements for irrigation with sewage water. J Irrig Drain Eng 113(4): 516-535.

7. Khan ZI, Safdar H, Ahmad K, Wajid K, Bashir H, Ugulu I \& Dogan Y (2020). Copper bioaccumulation and translocation in forages grown in soil 
irrigated with sewage water. Pak J Bot IN PRESS http://doi.org/10.30848/PJB2020-1(12).

8. Oron $\mathrm{G}$, Demalach $\mathrm{J}$ \& Bearman JE (1986). Trickle irrigation of wheat applying renovated wastewater. Water Res Bullet 22(2): 439- 446.

9. Ahmad K, Nawaz K, Khan ZI, Nadeem M, Wajid K, Ashfaq A et al (2018a). Effect of diverse regimes of irrigation on metals accumulation in wheat crop: an assessment - dire need of the day. Fresen Environ Bullet 27(2): 846-855.

10. Ahmad K, Kokab R, Khan ZI, Ashfaq A, Bashir H, Mudasra M et al (2018b). Assessment of heavy metals in wheat variety "Chagi-2'" under short-term wastewater irrigation. Biologia (Lahore) 64(1): 15-25.

11. Ahmad K, Ashfaq A, Khan ZI, Bashir H, Sohail M, Mehmood N \& Dogan Y (2018c). Metal accumulation in Raphanus sativus and Brassica rapa: An assessment of potential health risk for inhabitants in Punjab, Pakistan. Environ Sci Pollut Res 25(8): 16676-16685.

12. WRC (Water Research Commission) (2001). Effluent Reuse Demonstration Trials. Alexandria Effluent and Reuse Study, WRC Report No. ESRS, 15.

13. Benmouffok A (1994.) Characterization of sewage sludge from draa ben khedda and its partial use for agriculture purposes. University of Tizi-Ouzou Algeria 3: 295-299.

14. Khan ZI, Ahmad K, Nawaz K, Nadeem M, Ashfaq A, Munir B et al (2018a). Sugar industry effluents as a source of foil fertility and potential toxicological risk of heavy metals in food crop. Biologia (Pakistan) 64(II): 257-264.

15. Khan ZI, Ahmad K, Safdar H, Ugulu I, Wajid K, Bashir H \& Dogan Y (2018b). Manganese bioaccumulation and translocation of in forages grown in soil irrigated with city effluent: an evaluation on health risk. Res J Pharmaceut Biol Chem Sci 9(5): 759-770.

16. Khan ZI, Ahmad K, Iqbal S, Ashfaq A, Bashir H, Mehmood N \& Dogan Y (2018c). Evaluation of heavy metals uptake by wheat growing in sewage water irrigated soil. Human Ecol Risk Assess 24(5): 1409-1420.

17. Khan ZI, Ugulu I, Sahira S, Ahmad K, Ashfaq A, Mehmood N \& Dogan Y (2018d). Determination of toxic metals in fruits of Abelmoschus esculentus grown in contaminated soils with different irrigation sources by spectroscopic method. Int J Environ Res 12(3): 503-511.

18. Steel RGD \& Torrie JH (1996). Principles and procedures of statistics: $A$ Biometrical Approach, Mc Graw-Hill New York, pp 195-233.

19. Liu WH, Zhao JZ, Ouyang ZY, Soderlund L \& Liu GH (2005). Impacts of sewage irrigation on heavy metals distribution and contamination in Beijing, China. Environ Int 31: 805-812.

20. Cui YJ, Zhu YG, Zhai RH, Chen DY, Huang YZ, Qui Y \& Liang JZ (2004). Transfer of metals from near a smelter in Nanning, China. Environ Int 30: 782791.

21. Mirecki N, Agic R, Sunic L, Milenkovic L \& Ilic ZS (2015). Transfer factor as indicator of heavy metals content in plants. Fresen Environ Bullet 24(11): 4212-4219

22. Al-Hwaiti M \& Al-Khashman O (2014). Health risk assessment of heavy metals contamination in tomato and green pepper plants grown in soils amended with phosphogypsum waste materials. Environ Geochem Health 37(2): 287304.

23. Shahid M, Dumat C, Pourrut B, Abbas G, Shahid N \& Pinelli E (2015). Role of metal speciation in lead-induced 
oxidative stress to Vicia faba roots. Russ J Plant Physiol 62(4): 448-454.

24. Sajjad K, Farooq R, Shahbaz S, Khan MA \& Sadique S (2009). Health risk assessment of heavy metals for population via consumption of vegetables. World Appl Sci J 6: 16021606.

25. Wang X, Huan GW, Tian HG, Dong SR, Yin HG \& Cao XH (2007). Investigation on dietary of urban residents in Tiajin from 2000-2004, China. J Public Health 23: 12-45.

26. Wang X, Sato T, Xing B \& Tao S (2005). Health risks of heavy metals to the general public in Tianjin, China via consumption of vegetables and fish. Sci Total Environ 350: 28-37

27. USEPA (United States Environmental Protection Agency) (2002). Region 9, Preliminary Remediation Goals. Office of Research and Development, Washington, DC, USA.

28. Day AD, Ottman MJ, Taylor BB, Pepper IL \& Swingle RS (1990). Wheat responds to sewage sludge as fertilizer in an arid environment. $J$ Arid Environ 18(2): 239-144.

29. Farid S (2006). Status of cadmium concentration in soil and vegetables irrigated with city effluents, China. $J$ Appl Environ Biol 12(3): 414-419.

30. FAO/WHO (Food and Agriculture Organization of the United Nations/World Health Organization) (2001). Codex Alimentarius Commission. Food Additive and Contaminants. Joint FAO/WHO Food Standards Programme, ALINORM 01/12a, 1-289.

31. Miras JJR, Perez LR, Palomino MG, Boluda R \& Gill C (2011). Background levels and baseline values of available heavy metals in mediterranean greenhouse soils (Spain). J Geochem Explor 110: 186-192.
32. Zhou L, Yang B, Xue N, Li F, Seip HM, Cong X, Yan Y, Liu B, Han B \& Li H (2014). Ecological risks and potential sources of heavy metals in agricultural soils from Huanghuai plain, China. Environ Sci Pollut Res 21: 1360-1369.

33. Mitchells WL, Bingham FT \& Page AL (1978). Yield and metal composition of lettuce and wheat grown on soils amended with sewage sludge enriched with cadmium, copper, nickel, and zinc. J Environ Qual 7: 165.

34. Kashem MDA \& Singh BR (1999). Heavy Metals contamination in the vicinity of industries in Bangladesh. Water Air Soil Pollut 115(1-4): 347-361.

35. Martin S \& Griswold W (2009). Human health effects of heavy metals. Environ Sci Technol Briefs for Citizens 15: 1-6.

36. Hettiarachchi GM, Pierzynski GM, Zwonitzer J \& Lambert M (1997). Phosphourus source and rate effects on cadmium, lead, and zinc bioavailabilities in a metal contaminated soil. In: Extended Abstr., 4th Int. Conf. on the Biogeochem. Trace Elements (ICOBTE), Berkeley, CA. 23-26 June 1997. Int. Soc. For Trace Element Res., Berkeley, CA. 463-464.

37. Moradia A, Honarjooa N, Najafib P \& Fallahzadec J (2016). A human health risk assessment of soil and crops contaminated by heavy metals in industrial regions, central Iran. Human Ecol Risk Assess 22(1): 153-167.

38. Mohamed AR \& Ahmed KS (2006). Market basket survey for some heavy metals in Egyptian fruits and vegetables. Food Chem Toxicol 44: 1273-1278.

39. Colak H, Soylak M \& Turkoglu O (2005). Determination of trace metal content of various herbal and fruit teas produced and marketed in Turkey. $J$ Trace Elem Electroly 22: 192-195.

40. Kim IS, Kang HK, Johnson-Green P \& Lee EJ (2003). Investigation of heavy 
metal accumulation in Polygonumthunbergii for phytoextraction. J Environ Pollut 126: 235-27.

41. Al-Othman ZA, Ali R, Al-Othman AM, Ali J \& Habila MA (2016). Assessment of toxic metals in wheat crops grown on selected soils, irrigated by different water sources. Arab J Chem 9:15551563 .

42. Kaneta M, Hikichi $\mathrm{H}$, Endo $\mathrm{S} \&$ Sugiyama N (1986). Chemical form of cadmium (and other heavy metals) in rice and wheat plants. Environ Health Perspectives 65: 33-37.

43. Cailin GE, Yan D, Zegang W, Dingzhen W, Yulong W, Qi S \& Shishi L (2009). Responses of wheat seedlings to cadmium, mercury and Trichlorobenzene stresses. J Environ Sci 21(6): 806-813.

44. Ahmad I, Akhtar MJ, Zahir ZA \& Jamil A (2012). Effect of cadmium on seed germination and seedling growth of four wheat (Triticum aestivum L.) cultivars. Pak J Bot 44(5): 1569-1574.

45. Iannelli MA, Pietrini F, Fiore L, Petrilli L \& Massacci A (2002). Antioxidant response to cadmium in Phragmites australis plants. Plant Physiol Biochem 40(11): 977-982

46. Campbell PGC (2006). Cadmium-a priority pollutant. Environ Chem 3(6): 387-388.

47. Manahan SE (2003). Toxicological chemistry and biochemistry, $3^{\text {rd }}$ Edition. Lewis Publishers, 425.

48. Solomons NW (1998). Mild human zinc deficiency produces an imbalance between cell-mediated and humoral immunity. Nutr Rev 56: 27-28.

49. Greany KM (2005). An assessment of heavy metal contamination in the marine sediments of Las Perlas Archipelago, Gulf of Panama. Master of Science
Thesis, School of Life Sciences HeriotWatt University, Edinburgh, Scotland.

50. Hassan NU, Mahmood Q, Waseem A, Irshad M, Faridullah \& Pervez A (2013). Assessment of heavy metals in wheat plants irrigated with contaminated wastewater. Pol J Environ Stud 22(1): 115-123.

51. Jamali MK, Kazi TG, Arain MB, Afridi HI, Jalbani N, Kandhro GA, Shah AQ \& Baig JA (2009). Heavy metal accumulation in different varieties of wheat (Triticum aestivum L.) grown in soil amended with domestic sewage sludge. J Hazard Mater 164(2-3): 138691.

52. Meng W, Wang Z, Hu B, Wang Z, Li H \& Goodman RC (2016). Heavy metals in soil and plants after long-term sewage irrigation at Tianjin China: A case study assessment. Agric Water Manage 171: 153-161.

53. Harikumar PS, Nasir UP \& Rahman MPM (2009). Distribution of heavy metals in the core sediments of a tropical wetland system. Int $J$ Environ Sci Technol 6(2): 225-232.

54. Bao Z, Wu W, Liu H, Chen $\mathrm{H} \&$ Yin $\mathrm{S}$ (2014). Impact of long-term irrigation with sewage on heavy metals in soils, crops, and groundwater - a case study in Beijing. Pol J Environ Stud 23(2): 309318.

55. Uwah EI, Ndahi NP \& Ogugbuaja VO (2009). Study of the levels of some agricultural pollutants in soils, and water leaf (Talinum triangulare) obtained in Maiduguri, Nigeria. J Appl Sci Environ Sanit 4(2): 71-78.

56. Lago-Vila M, Arenas-Lago D, Rodriguez-Seijo A, Andrade-Couce ML \& Vega FA (2015). Cobalt, chromium and nickel contents in soils and plants from a Serpentinite Quarry. Solid Earth, 6: 323-335. 
57. Sihag S \& Lohchab RK (2017). Effects of sewage sludge bio-available heavy metals on agricultural soils and wheat crop. J Environ Biol Sci 31(1): 247-254.

58. Asdeo A (2014). Toxic metal contamination of staple crops (wheat and millet) in periurban area of western Rajasthan. Int Refereed Eng Sci 3(4): 818.

59. Bose S \& Bhattacharyya AK (2008). Heavy metal accumulation in wheat plant grown in soil amended with industrial sludge. Chemosphere 70(7): 1264-1272.

60. Huu HH, Rudy S \& Damme AV (2010). Distribution and contamination status of heavy metals in estuarine sediments near Cua Ong Harbor, Ha Long Bay, Vietnam. Geologica Belgica 13(1-2): 37-47.

61. Kwon YT, Lee CW \& Ahn BY (2001) Sedimentation pattern and sediments bioavailability in a wastewater discharging area by sequential metal analysis. Microchem J 68(2-3): 135-141.

62. Alghobar MA \& Suresha S (2015). Evaluation of nutrients and trace metals and their enrichment factors in soil and sugarcane crop irrigated with wastewater. J Geosci Environ Prot 3: 4656.
63. Balkhair KS \& Ashraf MA (2016) Field accumulation risks of heavy metals in soil and vegetable crop irrigated with sewage water in western region of Saudi Arabia. Saudi J Biol Sci 23: 32-44.

64. Osaili TM, Al-Jamalib AF, Makhadmeh IM, Tahaa M \& Jarrar SK (2016). Heavy metals in vegetables sold in the local market in Jorda. Food Addit Contamin 9(3): 223-229.

65. Khan S, Cao Q, Zheng YM, Huang YZ $\&$ Zhu YG (2008). Health risks of heavy metals in contaminated soils and food crops irrigated with wastewater in Beinjing, China. Environ Pollut 152(3): 686-692.

66. Singh A, Sharma RK \& Agrawal M (2010) Risk Assessment of heavy metal toxicity through contaminated vegetables from wastewater irrigated area of Varanasi. Tropic Ecol 51: 375387.

67. Muchuweti M, Birkett JW, Chinyanga E, Zvauya R, Scrimshaw MD \& Lester JN (2006). Heavy metal content of vegetables irrigated with mixtures of wastewater and sewage sludge in Zimbabwe: Implications for human health. Agric Ecosys Environ 112(1): 4148. 